\title{
'PEOPLE WITHOUT A STATE ALSO MUST LIVE': KURDS’ EXPERIENCES OF CITIZENSHIP IN THE MIDDLE EAST AND THE NETHERLANDS
}

\author{
NANNIE SKÖLD*
}

\begin{abstract}
Through considering the historical and ongoing systematic oppression of Kurds in the Middle East, this paper seeks to interrogate the role of citizenship in relation to processes of inclusion and exclusion within nation states. By situating the concepts of citizenship and statelessness within their appropriate political context, this paper explores the extent to which citizenship regimes can be used to serve the interests of the state and undermine the interests of minority citizens. This is analysed through considering the framework of the modern state system, in which individuals are largely dependent on citizenship for access to rights. The severe implications of non-citizenship increase citizens' dependency on states, increasing the capability of states to oppress minority citizens who are not considered to belong within the national community. Through navigating participants' narratives of citizenship and statelessness, a nuanced understanding of the role of citizenship will challenge dominant assumptions.
\end{abstract}

\section{TABLE OF CONTENTS}

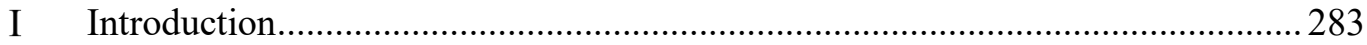

II Statelessness and the International State System ...........................................28 285

III Conceptualising Citizenship in Light of Ethnicity and Nationality …..................228

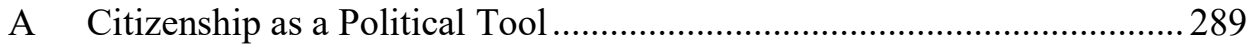

B Citizenship in Turkey, Syria, Iraq and Iran .........................................2290

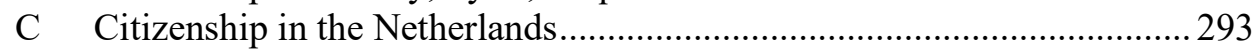

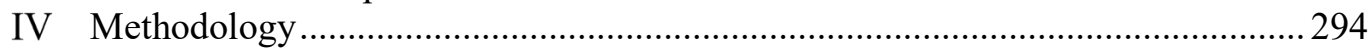

V Citizenship: A Certificate to 'Exist in the Given World' .....................................2295

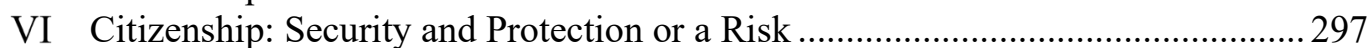

VII Citizenship: Representing the Idea of the Nation .................................................299

VIII The Role of the State and Citizenship in Addressing Exclusion ...........................300

IX Citizenship: A Tool of Assimilation and Oppression .............................................303

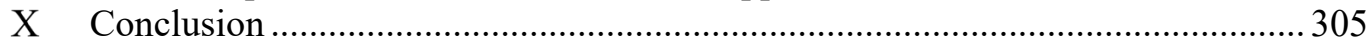

\section{INTRODUCTION}

Kurdistan is considered to be the world's largest nation without a state. ${ }^{1}$ Approximately 30 million Kurds are spread throughout the Middle East and through its diasporic population - Europe, the former Soviet Union, the Americas and elsewhere. ${ }^{2}$ Following the disunion of the Ottoman Empire, Kurdistan was briefly considered for recognition as a sovereign state, but this was never

* Nannie Sköld holds an MSc in Sociology: Migration and Ethnic Studies from the University of Amsterdam. This article is an amended version of her Master's thesis.

1 Loqman Radpey, 'Kurdish Regional Self-Rule Administration in Syria: A New Model of Statehood and Its Status in International Law Compared to the Kurdistan Regional Government (KRG) in Iraq' (2016) 17(3) Japanese Journal of Political Science 468, 470; Abbas Vali, 'The Kurds and Their "Others": Fragmented Identity and Fragmented Politics' (1998) 18(2) Comparative Studies of South Asia, Africa and the Middle East 82, 82.

2 Radpey (n 1) 470; Vali (n 1) 82. 
actualised. ${ }^{3}$ Instead, Britain and France (with Russian assent) partitioned the Kurdish population between the regions that would become the modern-day states of Turkey, Syria, Iraq and Iran, ${ }^{4}$ within which Kurds constitute minority groups. ${ }^{5}$ In the decades that have followed, Kurds have been victims of oppression and violence - conditions under which many have been forced to flee - and continue to be regarded as inferior to citizens of the nation-states' respective majority groups. ${ }^{6}$

This paper seeks to explore the exclusion of Kurds through the lens of citizenship and statelessness. It will look at the role of citizenship within the creation and maintenance of exclusion and ask what function citizenship can play in addressing this exclusion. The aim is not to compare the Kurdish regions of concern (Kurdistan-Turkey, Kurdistan-Syria, Kurdistan Region of Iraq and Kur distan-Iran), but instead to provide a nuanced understanding of the breadth and complexity of individuals' experiences of citizenship in the Middle East and as a diaspora population in the Netherlands. Literature on statelessness predominantly focuses on de jure statelessness and tends to frame the issue as a problem of lack of citizenship, whereby citizenship acquisition is understood as the solution to statelessness. ${ }^{7}$ Drawing on this literature, this paper acknowledges the paramount importance of legal citizenship status for the ability to access rights and recognition and to live a full life. However, based on this understanding, it is recognised that individuals are heavily dependent on states for such recognition. The paper here deviates from the dominant discourse on statelessness by assuming both the state and its inhabitants are political actors with particular interests. Due to the political and historical context of Kurdistan and its status as a stateless nation, the case of Kurdistan makes the political dimension of citizenship and statelessness explicit and unavoidable. Through understanding citizenship and statelessness to be political, and by coupling this with individuals' dependency on states for recognition as citizens, the notion of citizenship as a political tool will be developed.

This paper will start by looking at the role of states and citizenship within the modern state system in order explore the hegemonic framework through which states are considered to be emancipatory actors and citizenship is assumed to be a blanket solution to statelessness. These assumptions will then be broken down by taking a closer look at how legalistic notions of citizenship are intimately tied up with racialised, ethnicised and nationalist ideals. Furthermore, dominant global frameworks will be juxtaposed with individuals' lived experiences in order to

3 Radpey (n 1) 480.

4 ibid $469-70$.

5 Barzoo Eliassi, 'Statelessness in a World of Nation-States: The Cases of Kurdish Diasporas in Sweden and the UK' (2016) 42(9) Journal of Ethnic and Migration Studies 1403, 1405; Barzoo Eliassi, 'Conceiving Citizenship and Statelessness in the Middle East and Sweden: The Experiences of Kurdish Migrants in Sweden' in Nicole Stokes-DuPass and Ramona Fruja (eds), Citizenship, Belonging, and Nation-States in the Twenty-First Century (Palgrave Macmillan 2016) 85, 87-88.

6 Eliassi, 'Conceiving Citizenship and Statelessness in the Middle East and Sweden' (n 5); Ozlem Goner and Joseph T Rebello, 'State Violence, Nature, and Primitive Accumulation: Dispossession in Dersim' (2017) 41(1) Dialectical Anthropology 33; David Phillips, The Kurdish Spring: A New Map of the Middle East (Routledge 2015).

7 See, eg, United Nations High Commissioner for Refugees, Ending Statelessness within 10 Years (Special Report, 2010) ('Ending Statelessness within 10 Years; Institute on Statelessness and Inclusion, The World's Stateless (Wolf Legal Publishers 2014); European Network on Statelessness, Still Stateless, Still Suffering: Why Europe Must Act Now to Protect Stateless Persons (Report, 2014) ('Still Stateless, Still Suffering'). 
address individuals' structural dependency on the state in relation to the role of citizenship within individuals' visions for inclusion.

\section{Statelessness AND THE InTERnATIONAL StATE System}

Overwhelmingly, statelessness is a concept understood in terms of its legal definition as per the Convention Relating to the Status of Stateless Persons ('1954 Convention'). 8 Consequently, and in line with this legalistic understanding, citizenship acquisition and changes to states' citizenship laws are heralded as the solutions to statelessness. ${ }^{9}$ This dominant legalistic conceptualisation of statelessness has been criticised for having a restrictive legal focus and for overlooking broader systemic processes underlying statelessness. ${ }^{10}$ Within this context, statelessness will be explored as a broader sociological concept to be understood in relation to the international state system, in order to interrogate the role of citizenship in relation to the realisation of inclusion.

The scope of the issue of statelessness, and the profundity of its impact, can only be appropriately understood within the context of the hegemonic international state system. Primarily, Hannah Arendt significantly identifies statelessness as an iconic fallacy of the modern state system, ${ }^{11}$ and this analysis is echoed by a range of contemporary scholars who consider the global system of sovereign states to be the root cause of statelessness. ${ }^{12}$ Parallel to the state system according states the sovereign right to determine who is a citizen and who is not, the state has also acquired the responsibility of protecting the rights of the citizen and, by extension, the capability to deny the rights of individuals who the state determines to be non-citizens. ${ }^{13}$ In what Arendt refers to as the "tragedy of the nation-state', human rights are thereby increasingly granted on the basis of state recognition as a citizen, rather than on the basis of being human. ${ }^{14}$ Relatedly, conflicting international norms regarding human rights, peace preservation and the norm of state sovereignty embedded within the modern state system risk undermining the human rights norm at the expense of upholding the sovereignty

8 Convention Relating to the Status of Stateless Persons, opened for signature 28 September 1954, 360 UNTS 117 (entered into force 6 June 1960) art 1.

9 Ending Statelessness within 10 Years (n 7) 21-2. See generally The World's Stateless (n 7); Still Stateless, Still Suffering (n 7).

10 Tendayi Bloom, Katherine Tonkiss and Phillip Cole, 'Providing a Framework for Understanding Statelessness' in Tendayi Bloom, Katherine Tonkiss and Phillip Cole (eds), Understanding Statelessness (Routledge 2017) 1, 7-8; Patrick Hayden, 'From Exclusion to Containment: Arendt, Sovereign Power, and Statelessness (2008) 3(2) Societies Without Borders 249; Lindsey N Kingston, 'Worthy of Rights: Statelessness as a Cause and Symptom of Marginalisation' in Tendayi Bloom, Katherine Tonkiss and Phillips Cole (eds), Understanding Statelessness (Routledge 2017) 15; Latif Tas, 'How International Law Impacts on Statelessness and Citizenship: The Case of Kurdish Nationalism, Conflict and Peace' (2016) 12(1) International Journal of Law in Context 42.

11 Hannah Arendt, The Origins of Totalitarianism (Schocken Books 2004) 368.

12 See, eg, Tendayi Bloom, 'Members of Colonised Groups, Statelessness and the Right to Have Rights' in Tendayi Bloom, Katherine Tonkiss and Phillip Cole (eds), Understanding Statelessness (Routledge 2017) 153; Bloom, Tonkiss and Cole (n 10); Eliassi, 'Statelessness in a World of Nation-States' (n 5); Nell Gabiam, 'Citizenship and Development: Palestinians in France and the Multiple Meanings of Statelessness' (2015) 50(4) Studies in Comparative International Development 479.

13 Hayden (n 10) 253.

14 ibid 252; Arendt (n 11) 296. 
norm. ${ }^{15}$ Crucially, individuals are thereby highly dependent on recognition as citizens by the state in order to have their human rights protected. Thus, the idea of state sovereignty - sovereignty to determine who is a citizen and who is not, coupled with the role of ensuring human rights 16 - exacerbates the vulnerability of stateless individuals and strengthens the power of sovereign states.

Importantly, understanding statelessness as a consequence of the international state system provides an avenue for exploring statelessness as both an individual and a collective issue, often inextricably linked. ${ }^{17}$ As the issue of who is recognised as a citizen (and who is excluded) in the respective sovereign states is explored, the question of which nations are recognised as sovereign states (and which are not) comes to light. Statelessness thus becomes an issue not only of who is granted citizenship status within recognised sovereign states, but also of which states have been internationally recognised to hold this sovereign power of legitimate recognition. Following this, a conceptual distinction has been drawn between 'stateless persons', understood as individuals without formal citizenship status, and 'stateless peoples', referring to individuals who, regardless of formal citizenship status, are members of a stateless nation. ${ }^{18}$ Within the concept of the stateless nation is a recognition of the value of territory and sovereignty as well as an understanding of the state as an institution capable of preserving and fostering a cultural identity. ${ }^{19}$ In this paper, the distinction between stateless persons and stateless people will be used as a conceptual tool to aid our understanding of how 'Netherlands-based' Kurdish individuals experience and construct meaning around citizenship. ${ }^{20}$ Crucially, the notion of 'stateless people' does not necessarily suggest that the establishment of a sovereign state for this group is the most desirable outcome, as opinions within groups of stateless people can differ significantly. However, it does require that the notion of the (pre-existing) state as an emancipatory actor is problematised and that the presumption of citizenship as a blanket solution is challenged.

\section{CONCEPTUALISING CITIZENSHIP IN LIGHT OF ETHNICITY AND NATIONALITY}

Although the 1954 Convention grants legal protection exclusively to de jure stateless persons, ${ }^{21}$ the concept of de facto statelessness challenges the fundamental binary assumption of citizenship as something an individual either has or does not have. Crucially, understanding de facto statelessness as the status of possessing formal citizenship that is ineffective, ${ }^{22}$ begs the question of when citizenship is effective and when it is not, and acknowledges that citizenship cannot be reduced to solely denoting the possession of formal legal status. Carol

15 Miles Kahler, 'Legitimacy, Humanitarian Intervention, and International Institutions' (2011) 10(1) Politics, Philosophy \& Economics 20.

16 Hayden (n 10) 251-52.

17 Gabiam (n 12).

18 ibid 486; Thomas McGee, 'The Stateless Kurds of Syria: Ethnic Identity and National ID' (2014) 19(1-2) Tilburg Law Review 171, 172. Tas (n 10) makes a similar distinction, but uses the term 'social statelessness' instead of 'stateless people'.

19 Eliassi, 'Statelessness in a World of Nation-States' (n 5) 1412.

20 'Netherlands-based' is here used instead of 'Dutch' because a small number of the participants are only in the Netherlands on a temporary basis and do not consider themselves Dutch. However, most the individuals interviewed self-identify as Dutch.

21 Laura van Waas, Nationality Matters: Statelessness under International Law (Intersentia 2008) 22.

22 Hugh Massey, UNHCR and De Facto Statelessness (Background Paper, April 2010) 61. 
Batchelor uses the terms effective nationality and effective protection as tools to conceptualise the differences in quality of citizenship, suggesting that a technical legal definition can address solely technical and legalistic problems. ${ }^{23}$ In order to appropriately conceptualise these nuances, sociologically informed theories on citizenship will be used to explore citizenship within the context of Kurdistan.

A sociologically informed understanding of citizenship problematises the assumption that citizenship is universal. Isin and Turner suggest that citizenship is a concept located along three axes - extent, or who is included/excluded, content, or associated rights and responsibilities, and depth, in terms of its 'thinness' or 'thickness'. ${ }^{24}$ Whereas the dominant legal discourse around statelessness employs a 'thin' notion of citizenship, restricting the concept to denote only formal legal status, ${ }^{25}$ Isin and Turner's conceptualisation of citizenship problematises underlying assumptions of the dominant legal understanding of citizenship and statelessness. ${ }^{26}$ Using the three axes to conceptualise citizenship allows for nuances between different states' citizenship regimes, as well as disparities between citizens within the same state, to be explored. The assumption within the modern political idea of citizenship as universal, or 'implying the inclusion of all persons in full citizenship status under the equal protection of the law', ${ }^{27}$ is thereby challenged. By considering citizenship as complex and occurring along different axes, formal legal status is relegated to constituting merely one part of a broader concept of citizenship. Linda Bosniak explains that subordinated groups have at various points in history possessed legal citizenship yet continued to be excluded in other respects, referring to this as second-class citizenship. ${ }^{28}$ Bosniak expands on this by conceptualising formal citizenship as a mask through which the state operationalises its dominant idea of the nation, masquerading as the state's universal identity. ${ }^{29}$ Citizenship thus not only represents a particular idea of national identity as universal, but thereby also obscures structures of exclusion along the lines of gender, class, ethnicity, race, ability and age. ${ }^{30}$ Conceptualising citizenship as a broad sociologically informed concept including, but not restricted to, formal legal status, allows for Kurds' inclusion and exclusion within Turkey, Syria, Iraq, Iran and the Netherlands to be considered in a more nuanced manner.

Within everyday usage as well as legal discourse on statelessness, citizenship and nationality are conflated and both are understood as referring solely to formal legal status. ${ }^{31}$ Importantly, a sociologically informed understanding of the concepts of citizenship, nationality and ethnicity allow for differentiations to be

23 Carol A Batchelor, 'Stateless Persons: Some Gaps in International Protection' (1995) 7(2) International Journal of Refugee Law 232, 232.

24 Engin F Isin and Bryan S Turner, 'Citizenship Studies: An Introduction' in Engin F Isin and Bryan S Turner (eds), Handbook of Citizenship Studies (Sage 2002) 2.

25 Samantha Balaton-Chrimes, 'Statelessness, Identity Cards and Citizenship as Status in the Case of the Nubians of Kenya' (2014) 18(1) Citizenship Studies 15, 17.

26 Isin and Turner (n 24).

27 Iris Marion Young, 'Polity and Group Difference: A Critique of the Ideal of Universal Citizenship' (1989) 99(2) Ethics 250, 250.

28 Linda Bosniak, 'Constitutional Citizenship through the Prism of Alienage' (2002) 63(5) Ohio State Law Journal 1285, 1305.

29 ibid 1306.

30 Engin F Isin and Patricia K Wood, Citizenship and Identity (Sage 1999) vii.

31 Katherine Tonkiss, 'Statelessness and the Performance of Citizenship-As-Nationality' in Tendayi Bloom, Katherine Tonkiss and Phillip Cole (eds), Understanding Statelessness (Routledge 2017) 241. Notably, the United Nations High Commissioner for Refugees' Global Action Plan to End Statelessness (Report, 2017) uses the terms 'nationality' and 'citizenship' interchangeably. 
made between these distinct (albeit deeply interrelated) concepts and for the tensions between them to be explored. Although nation, nationality and nationalism are notoriously difficult to define, they will here be understood in accordance with Benedict Anderson's idea of the nation as 'an imagined political community', in which 'communities are to be distinguished, not by their falsity/genuineness, but by the style in which they are imagined'. ${ }^{32}$ The term 'imagined' is here used to suggest the non-prescriptiveness of the nation, rather than falsity. Although theorists such as Anthony Smith argue that the origin of nations lies in pre-existing ethnic populations, ${ }^{33}$ contemporary literature on nations and nationalism takes an overwhelmingly modernist approach, shifting away from the idea of the nation and ethnic groups as fixed entities. ${ }^{34}$ Rogers Brubaker argues that rather than treating ethnic, racial or national groups as externally bounded and internally homogenous entities, one should seek to consider ethnicity in terms of the process of ethnicisation. ${ }^{35}$ Accordingly, the concern of this paper lies in understanding how Turkey, Syria, Iraq and Iran became ethnicised nation-states and what role citizenship plays in relation to dominant ethno-nationalist conceptualisations. The status of Kurds as a minority ethnic group will be considered in light of the ethnicised processes of exclusion within the respective nation states of concern.

In exploring how citizenship relates to the concepts of nationhood and ethnicity, it is important to attend to the ways in which nation states require the formation of minority populations in order for a majority population to exist. Arjun Appadurai introduces the concept predatory identities, or identities that are conceptualised as being under constant threat from other proximate social identities and require their extinction. ${ }^{36}$ It is in situations where the notion of the 'imagined community' is reduced to an idea of ethnic singularity that minority identities come to be seen as deficits to the nation's purity and as threats to the continued existence of the ethnic majority group and thereby serve to legitimise the oppression of minority groups. ${ }^{37}$ Situating this within the international state system and the historical division of the Middle East into modern nation state entities, Kurds have been rendered a minority population in Turkey, Syria, Iraq and Iran rather than a majority population of a sovereign state. However, it is not necessarily the status as an ethnic minority group in itself that is problematic, but the status as a minority within ethno-nationalist nation states in which the respective majority populations are conceptualised as living under constant threat of minority populations. It is thus from within this context, coupled with the legitimacy of government afforded to states through the modern state system, ${ }^{38}$ that Kurds' exclusion and oppression ought to be understood and possible solutions can be conceptualised.

32 Benedict Anderson, Imagined Communities: Reflections on the Origin and Spread of Nationalism (Verso 2006) 6.

33 Anthony D Smith, The Ethnic Origins of Nations (Basil Blackwell 1986).

34 See, eg, Barry Hindess, 'Citizenship in the International Management of Populations' (2000) 43(9) American Behavioral Scientist 1486, 1491.

35 Rogers Brubaker, 'Ethnicity without Groups' (2002) 43(2) European Journal of Sociology $163,164,166$.

36 Arjun Appadurai, Fear of Small Numbers: An Essay on the Geography of Anger (Duke University Press 2006) 51.

37 ibid 51-3.

38 Hindess (n 34) 1494. 
There are two crucial points to consider in addressing the nexus between citizenship, nationality and ethnicity. Firstly, states have the sovereign right to determine their citizenship criteria as well as the power to restrict access to human rights for individuals who are excluded from those criteria. ${ }^{39}$ Thus, the extent to which the contours of the 'imagined community' are reflected in a state's citizenship criteria may differ, but where they are closely aligned the state generally has the authority to exclude potential citizens on such grounds. Secondly, Brubaker states that 'definitions of citizenship continue to reflect deeply rooted understandings of nationhood' ${ }^{40}$ suggesting that citizenship criteria reflect ideas of the nation as 'imagined' by the dominant group and might therefore not be representative of the citizens of the nation-state in question. As a consequence of the state's authority to determine its own citizenship criteria, Bosniak argues that citizenship can be used as a tool for institutionalising the dominant group's particular idea of nationhood and national identity. ${ }^{41}$ However, it is here valuable to consider Kristina Bakkær Simonsen's finding that citizenship policies can be less important in shaping one's sense of belonging than the boundaries of inclusion and exclusion drawn through political rhetoric and dominant conceptualisations of nationhood. ${ }^{42}$ Through Bakkær Simonsen's conceptual distinction between ascriptive criteria (such as having a particular ancestry) and attainable criteria (such as fluency in a language) needed to be recognised as a 'full' member of the national community, ${ }^{43}$ it becomes apparent that formal citizenship criteria constitute only one part of the threshold that must be overcome in order to be considered a full citizen.

\section{A Citizenship as a Political Tool}

Through considering statelessness and citizenship within their appropriate political context and identifying the actors involved and the interests of these actors, both statelessness and citizenship can be understood as functioning as political tools and, in some cases, as tools of oppression. In seeking to identify the interests of the state in light of the previous discussion on citizenship as a mechanism of inclusion and exclusion, citizenship will here be considered as a tool used by states to operationalise their vision of the boundaries of the national community. Crucially, the state's ability to exert its interests through citizenship is largely enabled through the sovereign rights granted to the state through the modern state system, alongside the reliance of individuals on states for citizenship in order to access rights and be recognised as existing within the given world order.

Although dominant discourse on statelessness conceptualises the state as an emancipatory actor and generally considers citizenship acquisition as a blanket

39 Hayden (n 10) 253.

40 Rogers Brubaker, Citizenship and Nationhood in France and Germany (Harvard University Press 1992) 3.

41 Bosniak (n 28) 1293, 1306.

42 Kristina Bakkær Simonsen, "Us" or "Them"? How Policies, Public Opinion, and Political Rhetoric Affect Immigrants' Sense of Belonging', Migration Information Source (online, 2019) <https://www.migrationpolicy.org/article/policies-public-opinion-rhetoricimmigrants-sense-belonging $>$.

43 ibid. 
solution to statelessness, ${ }^{44}$ it is essential that these notions be questioned. Primarily, the idea of citizenship as a blanket solution is problematised when considering citizenship as a broad sociological concept whereby formal legal status alone does not guarantee effective protection. Furthermore, the need to question the notion of the state as an emancipatory actor is particularly important when considering the situation of stateless people. Although members of different minority groups within a state may all be oppressed and excluded, it is crucial to recognise that the ways in which they wish for this exclusion to be addressed may differ. ${ }^{45}$ This is not to suggest that stateless people necessarily seek the formation of a sovereign state, but instead to argue that a desire for inclusion within the preexisting state cannot be assumed. When considering the context of struggles for self-determination, not only is independence from the pre-existing state explicitly sought, but the assumption of the state as an emancipatory actor could paradoxically serve to legitimise ongoing oppression. By recognising the political context in which statelessness takes place, coupled with the understanding of citizenship as a broad sociological concept, it becomes clear that the inclusion sought by stateless individuals or groups cannot necessarily be achieved through citizenship of the state in question. Thus, exploring the role of citizenship in addressing the Kurds' situation requires that the analysis does not start from the presumption of the pre-existing state as an emancipatory actor through granting formal inclusion in state citizenship regimes.

The aim here is by no means to suggest that de jure stateless persons cannot be oppressed by states. Rather, it is to recognise that both statelessness and citizenship can be used as political tools, including as tools of oppression. Citizenship regimes provide states with the power to (threaten to) deny citizenship or to denationalise certain individuals or groups as well as to use its legitimacy to govern in order to exploit citizens' subjugation and dependency on the state. The state's power is further exacerbated through the tendency to prioritise the norm of state sovereignty and thereby undermine efforts to protect human rights. ${ }^{46} \mathrm{Within}$ contexts of human rights violations, citizenship acquisition ought therefore to be understood as subjugation to a citizenship regime under the sovereign control of the state and thereby as creating a basis by which the international community can overlook human rights abuses. Thus, citizenship acquisition cannot be presumed to create inclusion, as it can also enable different forms of exclusion of persons and groups who are conceptualised as existing outside the boundaries of the national community in question.

\section{B Citizenship in Turkey, Syria, Iraq and Iran}

The notion of citizenship as deeply interrelated with dominant conceptualisations of the nation is integral to considering the ways in which citizenship regimes in Turkey, Syria, Iraq and Iran shape the processes of inclusion and exclusion of Kurds. Although each nation state's citizenship regime must be situated within its appropriate historical context, Barzoo Eliassi argues that citizenship is, in each of

44 Bloom, Tonkiss and Cole, 'Providing a Framework for Understanding Statelessness' (n 8) 2; Lindsey Kingston, 'Statelessness as a Lack of Functioning Citizenship' (2014) 19(1-2) Tilburg Law Review 132-23. See also Bloom, 'Members of Colonised Groups, Statelessness and the Right to Have Rights' (n 12) 154.

45 See Bloom, 'Members of Colonised Groups, Statelessness and the Right to Have Rights' (n 12) $153-54$.

46 Kahler (n 15). 
these nation states, understood as a heavily ethno-nationalist concept. ${ }^{47} \mathrm{He}$ suggests that the national identities are closely associated with being Turkish, Arab or Persian, respectively, and that these identities have been constructed partly through the suppression of Kurds. ${ }^{48}$ Building on this idea, Denise Natali suggests that '[w]hat it means to be a Kurd ... must be considered in relation to what it means to be a citizen of Iraq, Turkey, [Syria,] and Iran' ${ }^{49}$ Although the aim of this paper is not to compare experiences of citizenship between individuals from Kurdish regions in different nation states, exploring the boundaries of inclusion and exclusion in Turkey, Syria, Iraq and Iran, respectively, allows for expressions of Kurdish ethnic identity and nationalism to be situated within the contexts in which they have developed.

Since the formation of the Republic of Turkey in 1923, a distinction has continuously been made, whether explicitly or implicitly, between 'Turkishness as citizenship', where citizenship is defined as formal legal status, and 'Turkishness as such', despite claims to universality. ${ }^{50}$ Through state-driven processes of cultural assimilation, citizens were expected to assimilate to an idea of Turkishness that 'embodies, defends, and represents the particularity of ethnic Turkish identity'. ${ }^{51}$ Paradoxically, through showcasing Turkishness as unrelated to ethnicity, Kurds were not recognised as an ethnic group until 1991 and consequently denied, and continue to be denied, many cultural rights on the basis their ethnicity. ${ }^{52}$ Yegen suggests that the status of Kurds in Turkey has always been ambiguous, from predominantly being conceived of as 'prospective-Turks' to increasingly being seen as 'pseudo-citizens'. ${ }^{53}$ Whereas 'prospective-Turks' suggests that Kurds could be considered included within the Turkish national community when sufficiently culturally and linguistically assimilated, the idea of Kurds as 'pseudo-citizens' implies that 'some are more citizens than others' and that Kurds cannot achieve an equal level of Turkishness to others. ${ }^{54}$ Furthermore, Kurds have also been perceived as the Turkish nation's 'primary Other', or a minority group against which the majority can identify itself, rendering inclusion near impossible. 55

Syria offers perhaps the most explicit illustration of citizenship reflecting the dominant concept of the nation, as Syria's official name - Syrian Arab Republic - denotes the ethnicisation of its citizenship and conflates Arab ethnic identity with Syrian citizenship, whereby non-Arabs are considered less Syrian. ${ }^{56}$ Motivated by the idea that Kurdish presence was threatening the Arabic character of parts of the country, Syria implemented a census in 1962, resulting in

47 Eliassi, 'Statelessness in a World of Nation-States' (n 5) 1405.

48 ibid.

49 Denise Natali, The Kurds and the State: Evolving National Identity in Iraq, Turkey, and Iran (Syracuse University Press 2005) xviii.

50 Mesut Yegen, "Prospective-Turks" or "Pseudo-Citizens": Kurds in Turkey' (2009) 63(4) Middle East Journal 597.

51 Eliassi, 'Conceiving Citizenship and Statelessness in the Middle East and Sweden' (n 5) 95.

52 Ingmar Karlsson, Inga vänner utom bergen: Kurdernas historia (Historiska Media 2017) 115.

53 Yegen (n 50), 610.

54 ibid 610-11.

55 Mesut Yeğen, Müstakbel Türk’ten Sözde Vatandaşa (İletişm 2006) 74-143, cited in Cenk Saracoglu, "Exclusive Recognition": The New Dimensions of the Question of Ethnicity and Nationalism in Turkey’ (2009) 32(4) Ethnic and Racial Studies 640, 641.

56 McGee (n 18) 179; Eliassi, 'Conceiving Citizenship and Statelessness in the Middle East and Sweden' (n 5) 97. 
approximately 120,000 Syrian Kurds being stripped of their citizenship. ${ }^{57}$ However, since the start of the Syrian conflict in 2011, conceptualisations of citizenship have changed within the context of broader ongoing processes of social transformation. The conflict has given rise to claims for greater autonomy by Kurds and other ethnic minority groups and the idea to remove the term 'Arab' from the country's name has been under consideration. ${ }^{58}$ Furthermore, the Syrian state issued a decree in 2011 which made it possible for certain de jure stateless Kurds to (re-)apply for Syrian citizenship. ${ }^{59}$ However, the decision to grant certain Kurds Syrian citizenship was motivated predominantly by the state's political interests at the time, rather than by the intention to foster greater inclusion. ${ }^{60}$

Citizenship in Iraq has also undergone significant changes during the last eight decades due to violently explicit government policies of Arabisation from the 1930 s to the 90 s, during which Kurds and other ethnic minority groups were subjected to denationalisation, violence, massacres and systematic exclusion on the basis of their non-Arab ethnic identity. ${ }^{61}$ Natali argues that the pronounced pan-Arabism in Iraqi national identity fostered an increasingly ethnicised conceptualisation of Kurdish nationalism as a response. ${ }^{62}$ However, having undergone conflict and significant social transformation, the semi-autonomous Kurdistan Region of Iraq ('KRI') was established in 1991. 63 It is important to note that inhabitants of KRI are under Iraq's national jurisdiction and are, for the most part, citizens of Iraq, although inhabitants are also subjects of the Kurdistan Regional Government ('KRG'), to which political power has been partially devolved. ${ }^{64}$ The extent to which these Kurdish citizens identify with, or wish to be included in, the central Iraqi state is thus important to consider when looking at inclusion and exclusion of Kurds in KRI. Since the establishment of the KRG, both Kurdish and Arabic have been recognised as official languages in Iraq and KRI has arguably become more inclusive to minority ethnic and religious groups than central and southern Iraq, although KRI has also been repeatedly criticised for corruption, discrimination, nepotism and disparaging socio-economic inequality. ${ }^{65}$

As Iran officially became the Islamic Republic of Iran in 1979, the country cemented the religious foundations upon which the Iranian nation state was defined and thereby shifted ethnicity-based boundaries of exclusion to boundaries based on religion. ${ }^{66}$ However, as the dominant conceptualisation of the Iranian state continues to be firmly situated within a framework of Persian culture,

\footnotetext{
$57 \quad$ McGee (n 18) 173.

58 ibid 179 n 32; Anne Sofie Schøtt, The Kurds of Syria: From the Forgotten People to WorldStage Actors (Brief, Royal Danish Defence College 2017).

59 Schøtt (n 58) 15.

60 McGee (n 18) 178-9.

61 Human Rights Watch, On Vulnerable Ground: Violence against Minority Communities in Nineveh Province's Disputed Territories (Report, November 2009) 19; Karlsson (n 52) 14344; Elizabeth Campbell and Refugees International, The Faili Kurds of Iraq: Thirty Years Without Nationality (Report, 2 April 2010).

62 Natali (n 49) 48.

63 ibid 66

64 Bahar Baser, 'Homeland Calling: Kurdish Diaspora and Statebuilding in the Kurdistan Region of Iraq in the Post-Saddam Era' (2018) 27(1) Middle East Critique 78.

65 See ibid. See also Natali (n 49) 64; Karlsson (n 42) 155-56.

66 Natali (n 49) 140-41.
} 
language and historiography, ${ }^{67}$ assertions of Kurdish or other non-Persian identities are perceived as a threat to the Iranian nation state. ${ }^{68}$ However, the exclusion of Kurds in Iran has manifested itself differently than in Turkey, Syria and Iraq, as '[ $\mathrm{t}]$ he post-1980 Iranian Kurdish formula was based on the notion that Kurds and Iranians shared special ethnic, cultural, and linguistic ties that could not be constructed among Arabs, Turks, and Kurds'. ${ }^{69}$ Although crucial aspects of Kurdish culture and identity were prohibited, Kurdish identity was accepted to a greater extent than in Turkey. ${ }^{70}$ Furthermore, it has been argued that division in Iran has largely been on socio-economic terms and that Kurds in Iran considered themselves to have more in common with other oppressed groups within the country than with Kurds elsewhere in the region. ${ }^{71}$ Consequently, Natali argues that although Kurdish nationalism became ethnicised in response to the restrictions and militarisation of Iranian political space, Kurdish nationalism operated predominantly alongside other opposition movements in Iran. ${ }^{72}$

Kurdish ethnic identity and nationalism are here understood as being situated within particular nation state contexts and conceptualised in response to the lines along which Kurds experience exclusion from the national community. Natali suggests that

[e]thnicity became the basis of Kurdish identity not because it was rooted in some premodern past, but because it was the category of political identities used by central governments to determine inclusion and exclusion in the modern state system. ${ }^{73}$

Locating ethnicised Kurdish identity formation and nationalism within the citizenship regimes of the Middle Eastern states in question, Natali explains that 'Kurdish communities "Kurdified" what the state elite Arabized, Turkified, and Persianized'. ${ }^{74}$ Thus, Kurdish ethnicity ought to be understood, not as an essentialised feature, but as a response to the lines along which exclusion of Kurds has been articulated.

\section{Citizenship in the Netherlands}

The status of Kurds within the Netherlands necessarily differs from that within the nation-state contexts discussed above, as Kurds' presence in the Netherlands is intricately linked to migration and diaspora, rather than to the concept of homeland and claims to territory. As the Kurdish diaspora constitutes a significant proportion of the Kurdish population, it is important to recognise this difference in context without detracting from the ongoing processes of exclusion experienced by Kurds in countries such as the Netherlands. Within the Netherlands, citizenship is thought to be increasingly culturalised and virtualised - shifting from being a status recognised through formal legal status to one dependent on the citizen's degree of assimilation to dominant Dutch norms and values in order to be seen as

67 Kamal Soleimani and Ahmad Mohammadpour, 'Can Non-Persians Speak? The Sovereign's Narration of "Iranian Identity"' (2019) 19(5) Ethnicities 925, 928-36.

68 ibid 928.

69 Natali (n 49) 153.

70 Karlsson (n 52) 185.

71 ibid 203; Natali (n 49).

72 Natali (n 49) 149, 159.

73 ibid xxvi.

74 ibid 180. 
an actuality. ${ }^{75}$ Thus, a distinction is made between those with and those without Dutch formal citizenship status, and thereafter between Dutch citizens who are considered 'full citizens', or sufficiently assimilated, and those who are not. ${ }^{76}$ Furthermore, racialised hierarchies within the Dutch national community contribute to the continuous challenging of the legitimacy of minority citizens' inclusion and access to rights. Thus, whereas the access and content of the rights of minority citizens might not technically differ from citizens recognised as 'native', these racialised lines of exclusion render minority citizens' recognition as full citizens impossible. ${ }^{77}$ Thus, Kurds' exclusion in the Netherlands is shaped less by their specific Kurdish ethnicity and more by an ongoing racialisation as a non-Dutch visible minority.

\section{METHODOLOGY}

This study is based on interviews with 13 individuals (six women and seven men) in the Netherlands with a Kurdish background and aims to explore experiences and constructed meanings around citizenship and statelessness within a Kurdish context. The interviews were conducted face-to-face in either English or in Dutch with an interpreter. Both first- and second-generation Kurdish immigrants (from Kurdistan-Syria, Kurdistan-Turkey, Kurdistan Region of Iraq and Kurdistan-Iran) were interviewed and 10 of the 13 participants had Dutch citizenship. The interviewees had a range of different migratory histories, including arriving in the Netherlands as a refugee, through family reunification, as a student, and being born in the Netherlands. As a researcher with outsider status in relation to both Kurdish and Dutch identity, this will undoubtedly have shaped the responses of the participants during the interview as well as the analysis and conclusions drawn at the end of the study. Considering the restricted sample size, the aim of the study is not to provide a generalisable illustration of experiences of citizenship and statelessness from each of the regions and/or generations, but rather to develop a greater understanding of subjective realities of citizenship and statelessness and to situate this within a broader sociological framework. However, brief biographical details of the participants have been included alongside quotes in order to not mask potential specificities regarding regions, genders and ages.

Phenomenology was identified as a methodology well suited to achieve the aims of the study - namely, to explore individuals' experiences and construction of meaning around citizenship and statelessness within the context of Kurdistan. Phenomenology will for the purpose of this study be defined as 'a philosophy that ... [calls] for an analysis of "the things themselves", 78 and which recognises the individual as an agent. In this study, the significance of a phenomenological approach is crucial, as this approach allows for individuals' conceptualisations and experiences of concepts such as citizenship, statehood, nationalism and

75 Willem Schinkel and Friso van Houdt, 'The Double Helix of Cultural Assimilationism and Neo-Liberalism: Citizenship in Contemporary Governmentality' (2010) 61(4) The British Journal of Sociology 696, 702-4, 706-7.

76 See generally ibid.

77 Marieke Slootman and Jan Willem Duyvendak, 'Politics of Belonging, from National to Personal: The Political Framing of "Dutch" Identity and Ethnic Minority Citizens' in Nicole Stokes-DuPass and Ramona Fruja (eds), Citizenship, Belonging, and Nation-States in the Twenty-First Century (Palgrave Macmillan 2016) 55, 62; Pooyan Tamimi Arab, '(Dis)Entangling Culturalism, Nativism, Racism' [2012] (2) Krisis 68.

78 Thomas S Eberle, 'Phenomenology as a Research Method' in Uwe Flick (ed), The SAGE Handbook of Qualitative Data Analysis (Sage 2014) 194. 
statelessness to be at the forefront of the analysis and conclusions developed, regardless of the degree of consistency with dominant understandings of these terms. This is especially important considering that the term Kurdistan is envisioned in different ways among the participants - such as whether it includes all four regions, or as a geopolitical reality in Iraq — and thus shapes how citizenship, nationality and statelessness are conceptualised. The study seeks to problematise the dominant conceptualisations of citizenship and statelessness as they overlook more nuanced conceptualisations of citizenship and statelessness held by, among others, many Kurds. ${ }^{79}$ In order to explore this the concepts of citizenship and statelessness are approached phenomenologically, allowing for the narratives of individuals to be appropriately considered. This then allows for participants' narratives to be considered in light of dominant understandings of citizenship and statelessness and for the tension between these two conceptions, and its effect, to be analysed.

\section{Citizenship: A CertificAte to 'Exist in the Given World’}

Within the participants' narratives, differentiation and inequalities within citizenship regimes are discussed but, on several occasions, situated in relation to an actual or hypothetical status of non-citizenship. One participant from Kurdistan-Syria positioned his thoughts on Syrian citizenship within the historical context of the denationalisation of around 20\% of Syrian Kurds in 1962.80 Situating his own experiences within this context, he expresses:

For me, I had citizenship. I wasn't stripped of my citizenship because I lived in Afrin and mainly people from the north-east of Syria were stripped of their citizenship. But what I have seen and heard from people is that people couldn't do anything, anything. They went to school and they had final exams and they couldn't go to university because they didn't have any records. Having citizenship enabled me to study and go to university in Aleppo ... For me personally it was good to have it to be able to do many things, to go to university, but on the other hand it was awful. ${ }^{81}$

The 29-year-old participant echoes the notion of individuals' formal legal citizenship status as increasingly forming the basis upon which human rights are granted. ${ }^{82}$ The demarcation in access to human rights between citizens and noncitizens is made starkly visible in the context of Kurds in Syria through the disparity in access to rights between the Kurdish de jure stateless population and Kurds recognised as Syrian citizens. ${ }^{83}$ It is through recognising the sovereign rights of states, afforded through the international state system, to determine the criteria for citizenship, coupled with states' role in ensuring human rights, that individuals become dependent on state recognition in order to be able to access their human rights. ${ }^{84}$ Thus, the notion of the state as an emancipatory actor and citizenship as a solution to statelessness ought to be problematised. It can only be appropriately grappled with once the individual's dependency on state citizenship

79 Eliassi, 'Statelessness in a World of Nation-States' (n 5); McGee (n 18); Tas (n 10).

80 Tas (n 10) 45.

81 Interview with 29-year-old man (Kurdistan-Syria).

82 Hayden (n 10) 252.

83 Maureen Lynch and Perveen Ali, Buried Alive: Stateless Kurds in Syria (Report, Refugees International 2006) 1-2.

84 Hayden (n 12) 253. 
for human rights - a consequence of the modern state system - has been acknowledged. However, although the 29-year-old participant's citizenship crucially enabled him to access education and other rights, equal inclusion as a citizen in the Syrian national community cannot be assumed.

In moving away from looking at citizenship primarily in terms of the relationship between the citizen and the state, Barry Hindess argues that the concept of citizenship must also be considered in terms of its role within the modern system of dividing the world population into subpopulations under the governance of territorial states. ${ }^{85}$ It is through recognition as a citizen by a sovereign state that an individual is recognised as a member of the current world order and thereby - through the recognition as such a member rather than as 'merely human' - as a rights holder. ${ }^{86}$ In the narrative of a 25 -year-old woman from Kurdistan-Turkey, the participant reflects on the necessity of formal legal citizenship for recognition within the modern state system and explains that, "[f]or me, having a Turkish ID or Turkish passport ... was a matter of having a certificate or a card to exist in the given world'. Conversely, the 25 -year-old participant implies that if she were to not possess her Turkish or any other citizenship and thereby be rendered de jure stateless, she would not only be excluded from the Turkish state, but from membership to and recognised existence within the current world order.

However, understanding nations, and thereby also nation-states, to be artefactual constructions conceptualised as an 'imagined community', rather than organically deriving from pre-existing ethnic groups, the status as a citizen of a particular state does not inherently imply affinity. Situating her Turkish citizenship within the context of her Kurdish identity, the 25-year-old participant elaborates: '[t]he reason why I have a Turkish passport is because there is no Kurdistan, not because I live in another country as a minority. I live in my own land, man. I'm Kurdish, end of. Period.' Thus, in light of her previous statement, the participant suggests that the reason for her possession of Turkish citizenship is not primarily because she is Turkish, but because possession of citizenship is a fundamental requirement on both a domestic and global level. She suggests that she has Turkish citizenship precisely because Kurdistan is not a sovereign state, but that Turkey, in its capacity as an internationally recognised sovereign state, has the power to grant globally recognised citizenship, and thereby to provide a certificate to acknowledge and legitimate the existence of its citizens within the current world order.

The acquisition of Dutch citizenship is a valuable consideration where citizenship is coloured as a 'certificate ... to exist in the given world', whilst acknowledging the migratory history embedded within Kurds' recognition as citizens in the Netherlands. In particular, in cases where citizenship has been granted following recognition of an individual's refugee status, Dutch citizenship becomes intimately associated with protection within a context where the impossibility of individuals accessing rights and protection in the country of origin has been established.

The Dutch citizenship is like, it's great, and I appreciate it, but at the same time it's a reminder that I only have this because I can't have my own ... I feel like I only have Dutch citizenship because I'm actually stateless ... And because of the

85 Hindess (n 34) 1488.

86 Arendt (n 11) 373-75; Hayden (n 10) 256. 
situation in my country, my parents got it. My dad came to France as a political refugee. ${ }^{87}$

Dutch citizenship within this context becomes a necessity for access to rights and recognition. Within the context of recognition as a refugee, possession of Dutch citizenship implies the impossibility of accessing effective citizenship from one's homeland. In the case of the family of the 21-year-old woman, Kurdish citizenship could not be granted due to the non-existence of an internationally recognised Kurdish state, and the acquired citizenship of the recognised country of origin has, through the recognition of refugee status, been established as ineffective.

\section{Citizenship: SECURITY AND PROTECTION OR A RISK}

The participants' narratives illustrate the variation and differentiation across and, within citizenship regimes, suggest that citizenship is in some cases associated with security and protection and in other cases, with risk. Within the narratives, the Netherlands was the only state whose citizenship was considered to be associated with security and protection, although participants held different views regarding the degree to which state protection is differentiated among citizens and along what lines. A 21-year-old woman, who perceives Dutch citizenship to provide more protection for single than dual citizens (such as in cases of arrest abroad on political grounds), shares her reasoning in light of the risk she attributes to holding Turkish citizenship:

I'm trying to get rid of my Turkish citizenship. It's a fucking burden on my shoulders because all I'm thinking about is if I go to Turkey and I get arrested and I'm going to Turkey this summer - and I have dual citizenship, what's going to happen to me? If I only have Dutch citizenship I feel like it's more likely for the Netherlands to be able to pull me out of there and bring me back here ... But I don't know how to give back my Turkish citizenship without being on the radar. Because it's not like you just go and, 'here you go, no thank you' - you have to write an official request and state the reason for why you don't want to have it anymore. And if I'm not careful with that, that could mean that my name goes on some list. And then the moment I go to Turkey I get picked up ... I don't know when I should do it. If I should wait until I come back from Turkey, if I should do it before I go — what is smarter? I don't know. ${ }^{88}$

The 21-year-old suggests that she would have been more protected without Turkish citizenship - firstly, because she would face a lesser risk of being arrested if she was a non-citizen of Turkey and, secondly, because she would then expect to receive greater protection from the Dutch government as a sole Dutch citizen. The participant thereby raises the issue of the effectiveness of citizenship, or the idea that the quality of citizenship can differ within a particular citizenship regime, whereby it provides more effective protection for certain citizens than for others. ${ }^{89}$ Understood through Isin and Turner's framework of citizenship as being situated along different axes, ${ }^{90}$ the content, or associated rights and responsibilities, is understood to differ between single and dual citizens. The participant suggests that if she were to renounce her Turkish citizenship, she would

87 Interview with 21-year-old woman (Kurdistan-Turkey and Kurdistan Region of Iraq).

88 Interview with 21-year-old woman (Kurdistan-Turkey and Kurdistan Region of Iraq).

89 Batchelor (n 23).

90 Isin and Turner (n 24) 2. 
expect to be able to benefit from greater protection from the Dutch government, and thus be subject to more effective citizenship.

Crucially, the 21-year-old woman conceptualises Turkish citizenship as a threat to her safety, even when living in the Netherlands and possessing Dutch citizenship. Continuing her narrative by saying, 'It's really easy to be sent to prison these days. I have friends who were called to court for tweets against Erdogan', she refers to her perceived risk in terms of the anti-government sentiment expressed through her assertions of Kurdishness, rather than her Kurdish ethnicity per se. In order to address the risk of arrest and lack of protection, the participant plans to renounce her Turkish citizenship but fears that, in doing so, the Turkish government would pose an even greater threat towards her. Embedded within this narrative is the participant's awareness of states' authority to govern over their citizens, as well as the fact that efforts to uphold the norm of state sovereignty risk undermining international responses to human rights violations. ${ }^{91}$ Although the participant suggests that the Dutch government would recognise her hypothetical arrest on political grounds as a violation of her rights, she perceives the legitimacy of the Turkish state to govern over its citizens as posing an obstacle to the capability or willingness of the Dutch state to intervene on the grounds of ensuring protection of the rights of Dutch citizens. The participant's narrative thus emphasises how citizenship facilitates the ability of states to legitimately exert power on a discriminatory basis among its citizens. It is here important to recognise the state as a political actor with particular interests and thereafter that citizenship can be used as a tool by the state to further these interests, upheld by the modern state system.

In contrast to the narrative of the 21-year-old woman, a 54-year-old participant suggests that differentiation within the Dutch citizenship regime is largely along the lines of race, rather than a distinction between single and dual citizens.

In the Netherlands, I don't feel protected by the state. I have double nationality Turkish and Dutch — but even if I just had Dutch citizenship I can't feel the safety of a regular Dutch person. When a Dutch person comments on Turkey's actions, they are safe and they will be protected by the Dutch government. But, whether I have double nationality or not, if I react to some news on Facebook or social media, I don't feel so safe from the Dutch government to be so free in my speech and thought, even in Holland ... The Dutch government is actually not strongly protecting citizens who don't really have Dutch nationality. So I don't feel protection. I don't feel the freedom in the Netherlands to share my opinion over politics in Turkey. ${ }^{92}$

The notion of second-class citizenship is here invoked, suggesting that processes of exclusion of certain groups are ongoing even where equal legal status is formally recognised. ${ }^{93}$ However, the boundaries of exclusion illustrated by the 54-year-old participant are here conceptualised as a manifestation of structural racism through which the legitimacy of minority citizens' access to rights is continuously questioned. Here, exclusion is not attributed to Kurdish ethnicity in particular, but rather to racialisation as non-native Dutch. Although both participants above perceive their Dutch citizenship to be less effective than that of other particular groups of Dutch citizens - whether single Dutch citizens or

91 See Kahler (n 15).

92 Interview with 54-year-old man (Kurdistan-Turkey).

93 Bosniak (n 28) 1305. 
citizens considered to be 'native' — they differ in whether they attribute their differentiation to be due to attainable or ascriptive criteria. ${ }^{94}$ Whereas the 21 -yearold participant considers that she could renounce her Turkish citizenship in order to be granted more effective Dutch citizenship, the 54-year-old considers himself and other Kurds to be differentiated due to race and thus believes that there is no change within their control that would result in more effective protection.

\section{CITIZENSHIP: REPRESENTING THE IDEA OF THE NATION}

In many cases, participants' discussions around citizenship centred on ideas, experiences and historical narratives of oppression. All participants who spoke about citizenship in terms of oppression identified Kurdish ethnic identity as a basis of their oppression, but explanations differed greatly in terms of the underlying mechanisms of this exclusion. Some participants argued that Kurds are oppressed along with other minority groups as a consequence of their minority status within each nation-state, in line with Appadurai's idea of predatory identities. ${ }^{95}$ Several participants emphasised the intersectionality 96 of oppression, arguing that the oppression of Kurds and other minorities can only be appropriately conceptualised when accounting for the oppression experienced by segments of the Kurdish population on the grounds of gender, race, religion, sexuality, ability and class. Other participants suggested that the lack of Kurdish statehood in itself forms the underlying basis of their oppression and that it is only through the establishment of a Kurdish sovereign state that oppression against Kurds can be appropriately addressed.

Several participants expressed that, as part of a Kurdish ethnic minority, they did not feel part of the state of which they possess citizenship. A 32-year-old participant suggested that the possession of Iranian citizenship in itself did not render all citizens equal in Iranian society, and went on to highlight the intersectionality within experiences of oppression.

I think it is a problem that Kurdish people - but not just Kurdish people, but also Turkmens and Arabs in Iran - are oppressed by the Iranian regime because they are Kurds, they are Turks, they are Arabs ... Even though I had a nationality from Iran, being from Kurdistan of course came with oppression. Being oppressed also gave me a sort of identity that I was Kurdish, instead of being from Iran ... Kurdish people are oppressed because of their Kurdish background, but also others are oppressed - workers, women, young people ... So if you have your own state but you are a worker, then you are still oppressed by the state, by capitalism, as a worker. If you are a woman, you will still be oppressed because you are a woman. ${ }^{97}$

The participant starts by suggesting that citizens of Iran are differentiated on the grounds of ethnicity. The Iranian government's expressed desire for an

94 See Bakkær Simonsen (n 42).

95 Appadurai (n 36) 51-9.

96 Intersectionality refers to Kimberle Crenshaw's concept, used initially within the context of the marginalisation of black women in the United States' justice system. Intersectionality was coined to conceptualise the way in which black women are marginalised on the grounds of both gender and race. This experience of marginalisation cannot be reduced to the sum of its parts, but rather must be understood as specific to the ways in which these forms of marginalisation intersect and interact: Kimberle Crenshaw, 'Demarginalizing the Intersection of Race and Sex: A Black Feminist Critique of Antidiscrimination Doctrine, Feminist Theory and Antiracist Politics' [1989] (1) University of Chicago Legal Forum 139.

Interview with 32-year-old man (Kurdistan-Iran). 
ethnically singular Persian identity consequently renders any self-assertion by non-Persian minority groups to be seen as a threat towards the Persian majority ethnic group and the Iranian nation. ${ }^{98}$ In line with Appadurai's idea of predatory identities, it is this perceived threat and the idea of minority groups as a deficit to the ethnic purity of the nation that can 'unleash the urge to purify' and lead states to kill, torture and oppress minority groups. ${ }^{99}$ The extreme discrepancy between the idea of citizenship as universal and the violent differentiation between citizens on the basis of ethnicity thereby becomes painfully clear. The 32-year-old man continues by emphasising the differentiation that also occurs along the lines of gender, age and class. In order to form a comprehensive understanding of an individual's experience of oppression within citizenship regimes, an intersectional approach is therefore crucial. Bosniak's conceptualisation of citizenship as a mask - ostensibly universal but obscuring exclusionary structures along the lines of ethnicity, gender, class and more - thus serves to illustrate the differentiation, exclusion and oppression within citizenship regimes. ${ }^{100}$

Among participants from Kurdistan-Turkey in particular, Kurds' status within the nation-state is conceptualised largely in reference to politics of cultural assimilation and its expectation of adherence to ethnic Turkish identity and culture at the expense of assertions of Kurdishness. A 54-year-old participant explains that:

In order to survive in Turkey, you have to lose your own culture and lose your own language, so I didn't grow up with the Kurdish identity that I wanted and that I know exists. I knew that I was Kurdish but also that it was not right to act as a Kurd because it would create a situation. As a Kurd in Turkey, you have to adapt to Turkey to survive. 101

The 54-year-old man highlights that 'to act as a Kurd', or to assert a nonTurkish ethnic identity, was considered to fall outside of the dominant conceptualisation of Turkishness and result in severe repercussions. The distinction between 'Turkishness as citizenship' and 'Turkishness as such', and thus the ethno-nationalist terms through which the nation-state has been defined, thereby becomes clearly visible. ${ }^{102}$ Although assertions of Kurdishness in the past had been suppressed under the idea that 'there were no Kurds in Turkey', nonKurds later came to regard cultural and linguistic expressions of Kurdishness with a fear of racial extinction. ${ }^{103}$ Thus, the enforcement of cultural assimilation politics - aiming to shape the population in accordance with an ethnic Turkish ideal — ought to be contextualised within the majority group's fear of the minority.

\section{The Role OF THE STATE AND CITIZENSHIP IN AdDRESSING EXCLUSION}

Having briefly considered the exclusion of Kurds within specific nation state contexts, the aim of this section is to address the breadth of ways in which participants consider the questions of how, and into what, Kurds envision

98 Soleimani and Mohammadpour (n 67) 928.

99 Appadurai (n 36) 49, 53.

100 Bosniak (n 28) 1306.

101 Interview with 54-year-old man (Kurdistan-Turkey).

102 See Yegen (n 50).

103 Murat Ergin, 'The Racialization of Kurdish Identity in Turkey' (2014) 37(2) Ethnic and Racial Studies 322, 334. 
inclusion. Through considering Kurds' status as a stateless people, intersectional experiences of oppression, as well as the exclusion of other minority groups alongside the Kurds, the narratives of the participants will form the basis for an understanding of how Kurds envision inclusion. Importantly, in order to begin to conceptualise the idea of self-determination of any group, a distinction is required between who is included within this conceptual 'self' and who is not.

The majority of participants supported the idea of a sovereign Kurdish state, with one 28-year-old man from KRI expressing that, "[it] is the hope of every Kurd to have a Kurdish state. Then you have self-determination and you can make decisions by yourself, not other people with other interests and [other] ideas that make the decisions for you'. However, participants differed in who they imagined belonged within this state and how this state would differentiate itself from the nation-states from which autonomy was being sought. As individuals' conceptualisations of Kurdish identity, nationhood and statehood are partly shaped by the particular nation-state context of their own or their family's upbringing, a large number of research participants differentiate between Kurds from different regions. In turn, the way in which differences between Kurdish groups are conceptualised shapes how Kurdish inclusion is envisioned. Whereas a 23-yearold participant from Kurdistan-Syria explains that 'I never really knew that I was a Syrian Kurd - all I knew was that I was a Kurd, and that's it', another participant suggests that the division between the Kurdish regions is too great for a unified state to be successful, or even desirable.

Although all participants distinguished between Kurds through regions to some extent - even if it was with the intention to denounce this differentiation - many also emphasise the inherent value and importance of recognising and appreciating diversity. As is beautifully expressed by a 54-year-old participant:

In a garden with only roses, roses are beautiful, but the garden will be a little bit boring. If you have more flowers, it becomes more beautiful. It is like this in Kurdistan - we have lots of flowers and we have to cherish them. ${ }^{104}$

Kurdistan is here conceptualised as an entity that is strengthened, rather than threatened, by its diversity, in contrast to the concept of predatory identities, which can be applied to the majority ethnic groups in Turkey, Syria, Iraq and Iran. ${ }^{105}$ Many participants support the idea of a pluralist society, built on the tolerance of multiple values, beliefs and ethnicities, over the idea of creating additional boundaries between Kurdish regions. A participant from Kurdistan-Syria explains that 'I'm really pro the idea [of a pluralist society] because we Kurds suffered from that idea - to have one mono-culture, one mono-race in one geographical place and denying the rights of other people'. The participant thereby highlights that the root cause of the exclusion and oppression of Kurds does not lie in the fact that Kurds live within states also inhabited by people from other ethnic groups but rather in the prevalence of predatory identities fostering fertile ground for oppression.

The whole idea of a nation state ... I'm always afraid not to make the same mistake as our enemies, like impose one identity ... If we lived freely in Syria or Iraq, I

104 Interview with 54-year-old man (Kurdistan-Turkey).

105 See Appadurai (n 36) 51. 
think our aspiration of having a Kurdish state would not be as high as what we have now. But because you oppressed, people do the opposite. ${ }^{106}$

Here, the 29-year-old man emphasises the historical context of Kurdistan and suggests that attempts to address the exclusion and oppression of Kurds must consider from what it seeks to differentiate itself and how the institution of the nation-state might perpetuate the oppressive structures from which liberation is sought. The participant goes on to identify the reflexive nature of ethnicity and nationalism and suggests that the aspiration for a Kurdish state must be situated within the context of continuous exclusion from the nation-states Kurds inhabit. The participant's narrative thereby relates to the idea that Kurdish nationalism has developed, and become increasingly ethnicised, largely as a consequence of the increasingly ethnicisation of the national community's boundaries of inclusion and exclusion. 107

Several participants expressed that the establishment of a Kurdish state in itself is insufficient and that it is only when coupled with other advances in equality and rights that the establishment of a state can be part of a successful solution to address exclusion and oppression. A 32-year-old participant from Kurdistan-Iran expresses that 'Kurds have a right to a state. But that is not everything and that doesn't solve all problems'. However, the ideas shared by participants also differ according to whether they are imagining an ideal situation or suggesting practical steps to mitigate the exclusion of Kurds within current established institutional structures.

People without a state also must live. What Kurdish people actually stand for is a world without states. We believe that people shouldn't live within concepts of states but in the contemporary world it is complicated and we have a world system that means that you need a country, and identity and a passport for practical reasons. It is not so much for identity. Because in the world system today you are only protected when you have a passport from a certain state. I do have a Turkish passport but it is just for practical reasons and also for us it doesn't mean the same protection. For me, the best situation would be if we didn't have borders. ${ }^{108}$

The issues of citizenship and statehood here return to a discussion about the structure and implications of the international state system and the status of Kurds within this system. It is here valuable to return to the concept of stateless people and the notion of Kurdistan as a stateless nation - unrecognised and divided between states that are recognised as sovereign within the modern state system. ${ }^{109}$ Aside from the 1920s — the brief period in which Kurdistan was under consideration for recognition as a sovereign state ${ }^{110}$ — Kurds have inhabited nation-states as minority groups. ${ }^{111}$ Through the state system's division of the world population into subpopulations by territorial states and the legitimacy afforded to the governments of these states to govern the population on its territory, ${ }^{112}$ Kurds have been subjugated to governance by states who define

106 Interview with 29-year-old man (Kurdistan-Syria).

107 See Natali (n 49) 48; Vali (n 1).

108 Interview with 50-year-old woman (Kurdistan-Turkey).

109 See Vali (n 1).

110 Radpey (n 2) 480.

111 See Eliassi, 'Statelessness in a World of Nation-States' (n 5); Eliassi, 'Conceiving Citizenship and Statelessness in the Middle East and Sweden' (n 5).

112 Hindess (n 34) 1488. 
themselves through opposition to the Kurdish minority. ${ }^{113}$ As a stateless people, Kurds are thus governed by states who are internationally recognised as holding legitimate authority, but who have been, and continue to be, largely opposed to the existence of Kurds and Kurdishness.

\section{Citizenship: A Tool of Assimilation And OpPRESSION}

The status of Kurds as inhabitants within the sovereign states of Turkey, Syria, Iraq and Iran has given the governments of the respective states legitimate authority to exert power over the population in line with their own political interests. ${ }^{114}$ Furthermore, by recognising Kurds' position as minority groups within the four states as well as through understanding the identities of majority groups in the respective states as predatory identities, ${ }^{115}$ Kurds are understood to be at risk of being conceptualised as a threat to the nation and thus vulnerable to not only exclusion but also to oppression. Both citizenship and statelessness are conceptualised in this paper as political tools that can be used by states to serve their own interests, including their interest to oppress. By virtue of governments' legitimacy to govern populations in their territorial states, they use citizenship as a tool to further their own interests. This is achieved through decisions to deny citizenship or to denationalise certain individuals or groups, or the threat of doing so, as well as through techniques of government enabled by citizens' subjugation to the state's citizenship regime. As Turkey, Syria, Iraq and Iran have all instituted assimilation policies in the second half of the twentieth century, Kurdish citizens of these nation-states have been subjugated to measures intended to shape their behaviour and identity to conform to the states' ethno-nationalist conceptualisations of the national community. ${ }^{116}$ However, alongside shifts from viewing Kurds as prospective members of the nation to viewing Kurds as unassimilable, ${ }^{117}$ as well as the underlying conceptualisation of minorities as a threat, states' tactics of governing with the intention of achieving assimilation is inextricably linked with the aim to oppress. ${ }^{118}$

Most of the participants' narratives include personal experiences (relating to themselves as individuals or to their families) of state violence, including forced displacement. Although Kurds who are in the Netherlands, and thus are outside of the Kurdish regions in the Middle East, will presumably be disproportionately affected by forced displacement, the issue is crucial when considering the ways in which Kurds experience and construct meaning around citizenship. One participant summarises the oppression experienced by him and his family, and concludes that the Iranian regime is not only dictatorial, but also criminal.

I am in exile. I live in exile. We are only one family in Kurdistan: I am in exile, my uncle died in a clash, and my father was also terrorised by the Islamic regime. The son of my uncle is also in prison. This is only one family. So, that's why I say that this is a criminal regime. It's not only a dictator — it's criminal. ${ }^{119}$

113 Eliassi, 'Statelessness in a World of Nation-States' (n 5) 1405.

114 ibid

115 See Appadurai (n 36) 51.

116 Natali (n 49) xix; Radpey (n 2) 472.

117 On the shift in the conceptualisation of Kurds in Turkey from 'prospective-Turks' to 'pseudoTurks', see Yegen (n 50).

118 Eliassi, 'Conceiving Citizenship and Statelessness in the Middle East and Sweden' (n 5).

119 Interview with 29-year old man (Kurdistan-Iran). 
It is here crucial to situate the exertion of violence within the norm of state sovereignty in order to understand the extent to which state violence against its citizens can continue. Here it ought again to be acknowledged that oppression against Kurds is not due to their status as citizens. Rather, their status as citizens coupled with the international norm of state sovereignty can serve to partially protect the state from extensive international scrutiny or intervention, thereby allowing the state to continue its practice of oppression. ${ }^{120}$

Furthermore, oppression also operates through prohibition, of which there is a wide range of examples regarding Kurdish language, culture and assertions of identity within Turkey, Syria, Iraq and Iran. In the ethno-nationalist conceptualisations of the nation-states, the dominance of the language of the majority ethnic group has been integral to the idea of an ethnically singular nation. ${ }^{121}$ Thus, state-led efforts to assimilate minority groups through prohibition of markers of their ethnic identity ought to be conceptualised through an understanding of the majority population's view of Kurdishness as a threat to the national community. A number of the participants - both first- and secondgeneration immigrants to the Netherlands - do not speak any Kurdish language due to prohibitions on Kurdish language within their state of origin. The enforced prohibition on language is deeply interrelated with and dependent upon concurrent forms of state violence, which together, constitute an amplified form of oppression.

Strikingly, a number of participants explained how assimilatory measures of the Turkish state continue to be internalised and reproduced within the Netherlands. Participants listed examples from the Netherlands of where Kurds' social media accounts were being monitored and applications used to report nonconforming social media content to the Turkish government, and phones being tapped. Importantly, participants did not describe themselves as being under total surveillance, but the continuous possibility and threat of surveillance, as well as the trauma of oppression, has been observed by participants to lead to Kurds internalising the norms of the Turkish state.

The main thing I want to emphasise is the effect of statelessness still on people here in Europe - they are safe but they have a trauma and they are raising their children in the same way. They are raising them with a fear about the nations they come from. They don't teach their children their own identity, they don't teach them their own cultural origin. They don't teach them the languages, but instead teach them Turkish or Dutch, not Kurdish language. And trying to get their children safe because they are going to Turkey on holiday, and for the sake of their children's safety they are like assimilating but without the suppression anymore. The suppression is in them - they have internalised the suppression and the traumas. They are now acting by themselves like the countries that occupy Kurdistan wanted them to act. ${ }^{122}$

The participant here explicitly refers to the process of Kurds' internalisation of the norms of the Turkish state in his attempt to illustrate the extent to which Turkish citizenship has shaped the ways in which Kurds live, including in the relative safety of the Netherlands. Thus, he illustrates how the Turkish state's repression of Kurdish linguistic and cultural rights has widespread consequences

120 Kahler (n 15).

121 Soleimani and Mohammadpour (n 67); Yegen (n 50) 602.

122 54-year-old man (Kurdistan-Turkey) (emphasis added). 
beyond the territorial state and beyond the particular period of time in which direct prohibitive measures are enacted. The 54-year-old refers to the concept of statelessness to construct meaning around this experience, suggesting that the absence of a state to protect and preserve one's cultural identity constitutes a risk of cultural dispossession and is a marker of statelessness. ${ }^{123}$ Although the narratives of the research participants notably differ regarding their views on statehood, there is a recognition of the idea that the stateless nation's lack of a state can — but does not necessarily — lead to the repression and erosion of the minority group's cultural identity.

\section{CONCLUSION}

Through recognising the state as a political actor for whom citizenship can be used as a tool to serve its own particular interests, it becomes imperative to also recognise Kurds as political actors for whom citizenship acquisition, within certain contexts, can undermine collective interests. In recognising Kurds as political actors, it is crucial to ask the question of how Kurds experience and construct meaning around their historical and ongoing exclusion and oppression and how they wish for this to be addressed. When citizenship is recognised as political, it can no longer be assumed that Kurds necessarily wish for their exclusion to be addressed through citizenship to a nation-state that has repeatedly denied their full inclusion. The aim of the paper has been to explore the ways in which Kurds experience and construct meaning around citizenship. However, in order to do so, it becomes necessary to recognise the structural context within which Kurds carry out their lives - accessing education, marriage, traveling, fleeing — and the role of states and citizenship in this political reality. It is only once the structural dimensions of the modern state system, the sovereignty norm and the human rights regime have been considered that we can explore the lived experiences of citizenship in a manner that takes into account the political context within which these experiences are situated.

Through the phenomenological understanding of citizenship that emerges from the participants' narratives, a tension is introduced between citizenship as a structural necessity for individuals to access rights and recognition and citizenship as a tool that threatens to undermine collective interests. Through considering the role of citizenship in relation to collective interests, in terms of the existence and assertion of Kurdish ethnicity, formal citizenship status can be recognised as constituting only one aspect of inclusion. Therefore, when considering individuals' experiences of citizenship in relation to the collective (but not uniform) interests of Kurds, such as linguistic and cultural rights, the concept and impact of citizenship must be considered beyond its technical and legalistic definition. Whereas the discussion of Kurds' citizenship in the Middle East focuses on the exclusion and oppression of Kurds in light of their particular Kurdish ethnicity, the analysis of citizenship in the Netherlands highlights the broader processes of racialisation within citizenship regimes. When participants distinguish between the perceived level of Dutch state protection granted to themselves (as dual citizens and/or as racialised Others) and to a 'native' and/or single citizen, the modern state system's fundamental assumption of citizenship as universal is challenged. Instead, concepts such as ineffective citizenship and

123 See Eliassi, 'Statelessness in a World of Nation-States' (n 5) 1412. 
second-class citizenship are invoked and become useful tools for conceptualising variations and hierarchies within citizenship regimes. ${ }^{124}$ It raises the question of what inclusion in a state's national community entails and requires that inclusion be considered as a concept beyond formal citizenship status. Rather, it exposes the need to consider ongoing processes of ethnicisation and the role of ostensibly universal citizenship regimes in 'masking' underlying differentiation along the lines of ethnicity.

Ultimately, each participant's narrative contains stories of oppression. To consider the status of Kurds in Turkey, Syria, Iraq and Iran, it becomes imperative to not only ask what is required in order to be considered a full citizen, but also to seek to understand why Kurds have been systematically subjected to oppression. Appadurai's concept of predatory identities becomes a valuable conceptual tool for understanding how the majority groups of particular nation-states come to perceive themselves and the nation as being threatened by the existence of minority ethnic groups. ${ }^{125}$ Participants' narratives of cultural assimilation can thereafter be understood in light of the majority groups' fear of the assertion of minority identities. As narratives attest, this process can squander any assertion of Kurdishness to the extent that individuals develop a need to discipline themselves and their children to act in accordance with the norms of the majority ethnic group.

In focusing on the process of ethnicisation rather than on ethnicity as a bounded concept, it must be recognised that Kurdish ethnicity is complex and cannot be reduced to an externally bounded and internally homogenous entity. Relatedly, the ways in which Kurds conceptualise their exclusion and the grounds by which they advocate for their inclusion are largely reflective of the boundaries along which they have been excluded. Thus, the exclusion of Kurds within Turkey, Syria, Iraq and Iran is not inherent, but rather stems from the ongoing articulation of the national communities' boundaries of exclusion along the lines of ethnicity. It is here valuable to return to thinking about Kurdistan as a stateless nation. Importantly, referring to Kurds' status as a stateless people does not necessarily suggest that the establishment of a sovereign Kurdish state is the most desirable outcome for the group, as the breadth of opinions within the participants' narratives suggests. However, it does require that Kurdistan's historical context of being briefly considered, but never recognised, as a sovereign state is acknowledged when considering the notion of the state as an emancipatory actor. Furthermore, the analysis of Kurds in the Netherlands illustrates that differentiation and exclusion within citizenship regimes is ongoing beyond the historically Kurdish-populated Middle Eastern nation-states, albeit along different lines of exclusion. It thus becomes imperative to challenge the presumption of an ultimate desire to be included within pre-existing nation-states and instead demands that focus is placed on how Kurds envision their exclusion to be addressed and how they imagine inclusion.

124 Batchelor (n 23); Bosniak (n 28) 1305.

125 Appadurai (n 36). 